\title{
Middle East: \\ The Origins of the 'Islamic State' (ISIS)
}

\author{
Mediel HOVE
}

\begin{abstract}
This article examines the origins of the 'Islamic State' or the Islamic State of Iraq and Sham or Levant (ISIS) in light of the contemporary political and security challenges posed by its diffusion of Islamic radicalism. The Arab Spring in 2011 ignited instability in Syria providing an operational base for the terrorist group to pursue its once abandoned Islamic state idea. Its growth and expansion has hitherto proved to be a threat not only to the Middle East but to international security given its thrust on world domination. It concludes that the United States of America's activities in the Middle East were largely responsible for the rise of the Islamic State.
\end{abstract}

Keywords: Islamic state, Islamic radicalism, international security, Middle East.

\section{Mediel HOVE}

Research Associate,

International Centre for Nonviolence,

Durban University of Technology,

Durban, South Africa,

and

Senior Lecturer,

History Department, University of Zimbabwe

E-mail: medielhove@yahoo.co.uk

Conflict Studies Quarterly

Issue 23, April 2018, pp. 3-22

DOI:10.24193/csq.23.1

Published First Online: 04/10/2018

\section{Introduction}

The goal of this article was to examine the origins of the "Islamic State" (IS) or the Islamic State of Iraq and Sham (Syria) (ISIS), the Islamic State of Iraq and the Levant (ISIL) in light of the contemporary political and security challenges posed by its diffusion of Islamic radicalism in a drive to establish the Islamic State in Syria and Iraq. This is important given the fact that the roots of ISIS are under-examined in academic literature although they are tangentially covered in the media. This study augments those studies that have attempted to examine the roots of ISIS such as Gulmohamad (2014). It expands the limited understanding of ISIS's ideology, internal dynamics and war strategy and the state formation theories it embraced that made it difficult for the antiISIS forces to defeat it. 
The article asserts that ISIS had its roots in the Jamaat al-Tahwid wa-i-Jihad founded by Abu Musab al-Zarqawi, a Jordanian in 2002 which became highly active in the wake of the United States war in Iraq where it developed its ideology, vision and presence. Historically, it has been known by various names from Jamaat al-Tahwid wa-i-Jihad, al-Qaeda in Iraq, Majlis Shura al-Mujahedin, Islamic State of Iraq, Islamic State of Iraq and al-Sham/Levant to the present Islamic State. Initially, ISIS failed to realise its objectives when it attempted to connect its demands and aspirations to the popular struggle in Iraq where it intended to establish an emirate. It temporarily abandoned its Islamic state idea, perhaps in light of the American and allies' superior firepower. The withdrawal of the US forces from Iraq left a vacuum. Additionally, the Arab Spring in 2011 ignited instability in Syria and thus provided an operational base for ISIS. By 2015, its objectives were partly realised in Iraq and Syria where it conquered large parts, declared a Caliphate and temporarily ruled according to its dictates and radical interpretation of Islamic law-Sharia. This was achieved as a result of several factors which embody the pull out of the United States from Iraq, the group's leadership change that led to the rise to power of Al-Baghdad and the Arab Spring which culminated in the outbreak of the Syrian civil war.

ISIS is a transnational terrorist and Sunni Islamist insurgent group that caused instability and insecurity in the Middle East, especially in Iraq and Syria. It attracted international attention due to its devastating attacks and operations in Africa, the Middle East and Europe. Therefore, ISIS reveals the roots of a terrorist organisation whose growth and expansion hitherto proved to be a threat not only to the Middle East but to international security given its thrust on world domination. ISIS is more than a terrorist group because it is a politico-military club that embraces a radical version of Islam as a political idea and seeks to impose that worldview by might on Muslims and non-Muslims in an identical manner. Besides, ISIS's involvement in Syria, it spread instability beyond Syria's borders. The article concludes that the United States of America's activities in the Middle East were largely responsible for the rise of ISIS. To appreciate the origins of ISIS, the article engaged the qualitative methodology guided by the descriptive research design supported by primary and secondary sources in order to incorporate a variety of views. Primary sources used entail listening to leadership statements, speeches, audio and video messages made by or concerning ISIS found on YouTube and other internet sources. Again, secondary sources such as books, journal articles, newspapers and other media reports were consulted.

\section{ISIS's roots}

Various theories have been used to explain the formation of ancient and modern states. Although it is not the purpose of this article to discuss the theories that can be used to explain the establishment of ISIS it is vital to allude to these theories. It seems likely that ISIS embraced a significant number of state formation theories notably: conquest, 
voluntary, war and media theories. Evidently, there are a number of disputations among scholars concerning the origin of the state and its course of growth. Almost all state development theorists agree that to comprehend state formation one needs to grasp: "interstate relations and the relationship between the state and society ... Scholars disagree, however, over whether state formation is primarily a consequence of internal or external affairs" (Hadra, 2015, p. 41). Accordingly, it appears ISIS was influenced by the warfare, conquest, ideology or culture and global media theories among others in its formation and development.

The rise of ISIS can best and convincingly be explained through: the Zarqawi prelude (2002-2006) which was the period of jihadism's initial rise in Iraq, the Islamic State of Iraq (2006-2013), the Islamic State of Iraq and Sham (2013-2014) and the Islamic State as the outright caliphate (2014) (Bunzel, 2015, p. 1). The Islamic State is also known as ISIS, ISIL or Daesh, its Arabic acronym (Blanchard, Humud, Katzman, \& Weed, 2015; Gerges, 2014; Page, 2015). According to Cockburn (2014), the last "s" of "Isis" comes from the Arabic word "al-Sham", meaning Levant, Syria or occasionally Damascus, depending on the circumstances. It evolved from the Jordanian Abu Musab al-Zarqawi's Jamaat al-Tahwid wa-i-Jihad (JTWJ) founded in 2002. Zarqawi and his group played an important role in fighting the United States after its invasion of Iraq in 2003 and operated as a branch of Al-Qaeda since 2004 carrying out high profile terrorist attacks (Friedland, 2015). Following the killing of Zarqawi by the US and Iraqi intelligence agencies, Abu Ayyoub al-Masri, an Egyptian, came into view as the new leader who advocated for the establishment of an Islamic State of Iraq (ISI) (Gulmohamad, 2014, p. 1). It was observed that the JTWJ before it became ISIS:

... filled the security and governmental void created by the disintegration of the Iraqi army and Saddam Hussein's regime, accompanied by the increasing alienation of the Sunni Muslims from the central, Shi'ite-affiliated government in Baghdad sponsored by the United States (The Meir Amit Intelligence and Terrorism Information Center [ITIC], 2014, p. 2).

In this light, Gerges (2014) notes that the invasion of Iraq by US-led forces and their subsequent occupation of Iraq caused a break in the Iraqi society already fractured and bled by the many years of economic sanctions and war. More so, the destruction of Iraqi institutions by the United States, especially its dismantling of the Baath Party and the military created a vacuum that wrought fierce fighting for power and permitted the infiltration of al-Qaeda among other non-state actors into the delicate body of politics (Gerges, 2014). As a branch of Al-Qaeda, the JTWJ gradually established itself in Iraq during the fighting against the United States and its allies and finally adopted the name the Islamic State in Iraq (ISI), and became an important force among the antiAmerican insurgents (ITIC, 2014, p. 2). To this end, while "... ISIS is an extension of the global jihadist movement in its ideology and worldview, its social origins are rooted 
in a specific Iraqi context, and, to a lesser extent, in the Syrian war that has raged for almost four years" (Gerges, 2014, p. 339).

Unlike al-Qaeda's central organization which emerged from a pact between ultraconservative Saudi Salafism and radical Egyptian Islamism, ISIS came from an unholy union between an Iraq-based al-Qaeda affiliate and the vanquished Iraqi Baathist regime of Saddam Hussein which hitherto has proved a lethal arrangement (Gerges, 2014). However, it was weakened during the US/Iraq anti-terror war campaigns between 2006 and 2007 (Holmquist, 2015, p. 10). Regardless of that, Creamer (2014) asserts that the Iraq war radicalized many vulnerable young people and the Sunni power vacuum created by the US policies and Al-Maliki's policies motivated the extremists to take over large territories. This became realistic following the total withdrawal of the US forces from Iraq and the outbreak of the Syrian civil war in 2011. This witnessed the re-emergence of ISIS surpassing its previous actions and strength and strongly threatening the sovereignty of Iraq and other states in the Middle East (Holmquist, 2015). Accordingly, "ISIS is a symptom of the broken politics of the Middle East and the fraying and de-legitimation of state institutions, as well as the spreading of civil wars in Syria and Iraq" (Gerges, 2014, p. 339).

Delineating the formation of ISIS, Mehta (2016) notes that:

The birth of ISIS/Al-Qaeda and other terrorists groups came into being because of:

- Vacuum created by withdrawal of US forces from Iraq-Instead US planted militias in Iraq like SAS who were caught red handed while making bombs.

- Massive aid ( $\$ 3$ billion in two years) given by Saudi Arabia and Qatar to former army officers of Saddam Hussein. These officers ruled Iraq for 35 years and were ready for action to follow Saudi and Qatari military agenda.

- Support of Muslim brotherhood.

- Supporting of Kurdistan forces led by Nechirvan Barzani (Nechirvan).

- A compliant media with depictions of hate, violence and terror creating fear (Mehta, 2016, p. 3).

\section{The rise and fall of Jamaat al-Tahwid wa-i-Jihad and the creation of al-Qaeda in Iraq}

Al-Zarqawi was born Ahmad Fadhil Nazzal al-Khalaylah, in Zarqa, northeast of Amman, Jordan. He was from the Bani Hassani tribe. He had no education as he dropped out of school when he was at secondary school (Weiss \& Hassan, 2015). Al-Zarqawi was neither a great warrior nor a scholar but a thug and man of the street. He was involved in: alcohol use, the sale of drugs, fights and had tattoos which made him unsuitable as a leader of a radical religious group. However, his excessive ideas and the forcefulness of his character impelled him into this role (Warrick, 2015). His first experience with 
Salafism as a doctrine started when his mother sent him to do religious courses at the Al-Husayn Ben Ali Mosque in Amman. The doctrine calls for a return to theological purity and Prophet Muhammad's traditions. To Salafists, Western style modernity and democracy is irreconcilable with Islam. It is the one which largely polluted Arab civilisation. Consequently, this view influenced Zarqawi and the groups that succeeded the ones he led (Weiss \& Hassan, 2015).

Al-Zarqawi got experience as a Jihadi in Afghanistan when he fought against the Soviet Union invasion but did not do much as he joined when the war was at its end. This prompted him to return to his home country, Jordan where he was sentenced for 15 years in Jordanian prison on terrorism charges. However, he did not serve the sentence because he was pardoned in 1999 after King Abdullah II came to power (Weiss \& Hassan, 2015). According to Weiss and Hassan (2015), prison was Al-Zarqawi's university. It turned him into a more focused, brutal and decisive individual. It was during his time in prison that Al-Zarqawi reconnected with Abu Muhammad al-Maqdisi, a jihad theorist whom he had met in Afghanistan during the early 1990s. Al-Maqdisi's fundamentalist views of Islamic theology and jurisprudence also influenced Al-Zarqawi (Holmquist, 2015). Al-Maqdisi's teachings adopted by Zarqawi include the doctrine of al-Wala' w-al-Bara, which is loosely, translated "Loyalty and Disavowal". The doctrine asserts that Muslims ought to have an absolute loyalty towards, and love of, God and the Sharia, his law. Again, it means that Muslims be obliged to detach themselves and renounce everything that oppose the Sharia, especially democracy (Holmquist, 2015).

While JTWJ is viewed in other circles as an offshoot of al-Qaeda in Iraq (AQI) (Gulmohamad, 2014), Al-Zarqawi's group was initially focused on effecting regime change in Jordan (which led to Zarqawi's imprisonment) (Friedland, 2015). The rest of the world was to be conquered after regime change in Jordan but the goal was changed over time (Zelin, 2014). Although Al-Zarqawi and Osama bin Laden (the founders of both ISIS and al-Qaeda respectively) came of age during the jihad in Afghanistan against the Soviet Union, their socio-economic backgrounds were different. Whereas Osama bin Laden and his closest associates were from the middle class and had university education, Zarqawi and his closest compatriots were from poor and less educated backgrounds (Friedland, 2015; Zelin, 2014). This prompted differences and friction between the two leaders' organisations witnessed today which were sowed as soon as the two met in 1999 (Zelin, 2014). It was during Al-Zarqawi's second tour in Afghanistan that he ran a training camp for jihadists from the Levant. He trained amnesty beneficiaries released from a Jordanian prison together with him. He was critically assisted by the military commander of al-Qaeda, an Egyptian by the name Saif al-Adel to overcome the many challenges he faced in settling in Afghanistan. Additionally, Osama bin Laden gave him a small amount of seed money (USD 200, 000) which continued to the time of the 9/11atacks (Weiss \& Hassan, 2015; Zelin, 2014). 
However, Al-Zaqawi is viewed as having had a different and infrequently overlapping agenda with al-Qaeda. Although Zarqawi's public speaking was the same with that of Bin Laden, his targets were rather different. From the onset, Zarqawi directed his wickedness at colleague Muslims, principally Iraq's mainstream Shiite population. Bin Laden and al-Qaeda considered the Shiites as heretics but seldom targeted them for killing (Ghosh, 2014). Attempts by Osama bin Laden to fully co-opt him by requesting a religious oath (baya) saw Zarqawi repeatedly rebuffing it (Zelin, 2014). He fled in 2002 going to a Kurdish-dominated area in Iraq held by Ansar-al-Islam, an al-Qaeda linked group (Holmquist, 2015). The United States' Colin Powell made Zarqawi known when he wrongly publicised at the United Nations in 2003 that Zarqawi was the link between al-Qaeda's 9/11 attacks and Saddam Hussein in an attempt to make a case for invasion (Warrick, 2015). Inadvertently, this made Zarqawi famous.

Zarqawi travelled a lot before the US invasion of Iraq going to and from various places that include Iran, Iraqi Kurdistan, Syria, and the Sunni Triangle in Iraq in an effort to gain new jihadist contacts. He only became famous half a year following the invasion of Iraq by the US because of his brutal suicide bombing campaigns and personal beheadings directed at Shiite religious persons and Sunni civilians among many (Zelin, 2014; Hadra, 2015). This earned him the title "sheikh of the slaughterers" (Warrick, 2015; Weiss \& Hassan, 2015). It was these successes that motivated many foreign fighters to want to join him leading the group to need more resources to pursue and expand its operations (Zelin, 2014). Zarqawi's group's goals at that juncture was to drive the US forces out of Iraq, remove from power the Iraqi government and consequently purge the country of all Shia Muslims and create a pure Muslim state.

According to Altschular (2015), Zarqawi dismissed Americans as the most cowardly of creatures, who were supposed to be forced to leave the country as a matter of urgency. Again, he viewed the Shiites in Iraq as the "insurmountable obstacle", that needed primary attention as he saw them as "the lurking snake, the crafty and malicious scorpion, the spying enemy, and the penetrating venom" (Altschular, 2015). He also viewed the Shia in Iraq as the "the chief threat to Sunni power in Iraq and the wider region" (Hadra, 2015). In October 2004 he decided to proclaim the oath of allegiance (bay'a) to Osama bin Laden. Afterwards, JTWJ then fighting the United States invaders in Iraq renamed itself Qai'dat al-Jihad fi Bilad al-Rafidayn (Al-Qaeda in the Land of the Two Rivers, or commonly known in the West as al-Qaeda in Iraq, AQI) (Holmquist, 2015). Clearly, al-Qaeda's official endorsement and financial support made Zarqawi's promises to destabilize Iraq and arouse Sunnis to annihilate Shiite apostates to be realised. Zarqawi and his group looked forward to "take advantage of the resulting chaos to cast itself as the defender of the Sunni community and to usher in the establishment of an Islamic state" (Lister, 2014). 
The proclamation of baya to Osama bin Laden by Zarqawi was a marriage of convenience which sowed seeds for future conflicts evident in the conflict that has emerged between the two late leaders' groups today (Zelin, 2014). However, it was strategic for Zarqawi because it gave him access to benefits that included but were not limited to: “... private donors, recruitment, logistics and facilitation networks" (Tucker, 2014). As an al-Qaeda network, AQI controlled many important informal networks that range from the flow of resources and foreign fighters to gaining loyalty from individual fighters which eventually became critical for the continuation of the jihadist movement and this was apparent since 2010 (Zelin, 2014). In this regard, the Syrian case is a good example that attests the importance of the relationships and contacts obtained during the Iraq fighting. Like AQI and before, the organization infrequently attacked "... U.S. army installations, Iraqi authorities, the population and also targeted and assassinated Western citizens" (Blumenau, 2014). It raised its funds through various methods that ranged from robbing banks, taxing the victims of their terrorist activities, stealing trucks, abductions and ransoms among others which the group continue to use.

\section{The fall of AQI and the creation of the Islamic State}

The Mujahidin Shura Council (MSC) also known as Majlis Shura al-Mujahedin (MSM) was founded in 2006 by Al-Zarqawi as a calculated manoeuvre to move away from al-Qaeda. It came into being against the backdrop of the suffering from legitimacy crisis by AQI due to the foreign composition of its fighters that fought against the United States and lacked a real touch with the problems in the struggle (Holmquist, 2015). In this light, the MSC was established to unify the jihadist groups fighting in Iraq and to give AQI an Iraqi identity. About eight factions of Jihadist groups constituted MSC including AQI. As a result, AQI (under MSC as ISIS in the making) exploited the grievances of Sunnis particularly their disempowerment that was brought by the ascendancy to power of the Shia. This led Iraq Sunnis to protest their marginalisation and discrimination. However, their objections were not heard in both Baghdad and Washington creating an opportunity for ISIS to intervene instrumentalizing their grievances (Gerges, 2014). According to Patel (2015), those who were opposed to the United States occupation included:

... Baath Party loyalists hoping to return to power, as well as what were often informally described by occupation officials as POIs, or "pissed-off Iraqis": former public sector employees and soldiers who had lost their jobs, families who felt disrespected by counterinsurgent activities, and Iraqi nationalists motivated to resist foreign occupation. Islamist and nationalist insurgents often engaged in pragmatic alliances of convenience ... (p. 2).

Apparently, these groups of people formed a more than willing and ready recruitment base for ISIS's predecessors as they were motivated by the need to reverse their marginalisation and discrimination and ultimately regain political power, respect and dignity. 
The death of Al-Zarqawi in June 2006 at the hands of the United States and Iraq intelligence agencies led to the emergence of an Egyptian, Abu Ayyoub al-Masri as the new leader of AQI. This also marked the change of the group's direction and goals. He is the one who advocated for the cause of an Islamic State of Iraq (ISI) (Gulmohamad, 2014). The change of the group's name in October 2006 to Islamic State in Iraq (ISI) heralded the beginning of the group's focus on conquering Iraqi territory in an effort to create a sharia-based state (Friedland, 2015; Zelin, 2014). However, ISI efforts in this regard during this period were abortive. This is because tribal militias supported by the United States managed to defeat ISI with the help of the local population who turned against ISI due to its brutal methods of enforcing sharia (Zelin, 2014). Resultantly, ISIS emerged as a combination of the original AQI, the Mujahideen Shura Council in Iraq and the Jund al-Sahhaba (Soldiers of Prophet's Companions). Unfortunately, Sahwat al-Anbar which played a critical role in defeating the ISI (between 2006 and 2007) was not integrated into the Iraqi military which instead targeted them as a potential threat to Shiite majority rule. This made many of them to join ISI when it re-emerged in 2010 (Zelin, 2014). Evidently, ISI efforts to build an Islamic state had brighter fortunes in Iraq and Syria since 2011.

In the same vein, Patel (2015) summed up ISIS's origins when he noted that:

ISIS developed out of a string of predecessor insurgent organizations that operated in Iraq between 2003 and 2013, most notably "al-Qaeda in the Land of the Two Rivers," commonly known as AQI. Although Iraqis over time increasingly filled the cadres of AQI, the organization's leadership and early fighters were largely non-Iraqi Arabs, including its most well-known leaders, the Jordanian Abu Musab al-Zarqawi (d. 2006) and the Egyptian Abu Ayyub al-Masri (d. 2010), as well as the leaders of the wider al-Qaeda network (p. 2).

Related to the above citation, Zelin (2014, p. 1) has offered a history of ISIS's names as: Jamaat al-Tawhid wa-l-Jihad between 1999 and 2004; Al-Qaeda in the Land of the Two Rivers, or AQI between 2004 and 2006; Majlis Shura al-Mujahedin (MSM) (or Mujahedin Shura Council (MSC) in 2006; Islamic State of Iraq between 2006 and 2013; and Islamic State of Iraq and al-Sham from 2013 to the present (2014). However, at the end of June 2014 ISIS rebranded itself the Islamic State following its proclamation of a Caliphate in the areas it conquered in Iraq and Syria (Weiss \& Hassan, 2015).

In 2010, Baquba in Iraq was established as ISIS's headquarters by the emir Abu-Baker al-Baghdadi. His real name is not clear as others say he is also known as Abu Dua and his real name was Hamed Dawood Mohammed Khalil al-Zawi (Gulmohamad, 2014; Page, 2015). On the other hand, Cockburn (2014) notes that Baghdadi's real name was Awwad Ibrahim Ali al-Badri al-Samarrai. However, what is clear is that Al-Baghdadi is of Iraqi origin and was announced as the outfit's new leader following the killing of Al-Masri by the United States and Iraqi forces in 2010. According to Warrick (2015), Al-Baghdadi was 
part of the Zarqawi network at the beginning of the organisation's operations in Iraq. He was not a typical warrior insurgent nor was he known for bravery on the battlefield. Instead he was an Islamic scholar and had his carrier inclined to be spent as a college professor teaching Islamic law had the Iraq invasion not occurred. This is because he spent most of his time studying the Quran, the Hadith and the sayings of the prophets and understanding each detail and legal nuance. The establishment of al-Qaida in Iraq headed by Zarqawi came along with the need for religious scholars who could give him cover, bless his undertakings and guarantee his followers that killing people made them good Muslims. Indeed, Al-Baghdadi specialised in this but resultantly rose through the ranks for several years until 2010 when he assumed the leadership of the organisation when other leaders of the Islamic State were killed (Warrick, 2015).

In addition, Cockburn (2014) points out that while there are disputes over his career depending on the sources (whether ISIS itself or US and Iraqi intelligence), generally the representation is reasonably clear. Al-Baghdadi was born in Samarra, a Sunnidominated city north of Baghdad, in 1971 and is learned. He holds degrees (including a doctorate) in Islamic Studies, together with poetry, history and genealogy, from the Islamic University of Baghdad. Contrary to Warrick's (2015) view of Baghdadi as merely a scholar, Cockburn (2014) asserts that he may have been an Islamic militant under Saddam as a preacher in Diyala province, to the north east of Baghdad, where, after the US invasion of 2003, he had his own armed group. Insurgent movements have a strong motive for giving out misleading information about their command structure and leadership, but it appears al-Baghdadi spent five years as prisoner of the Americans.

The above citation is appealing in light of Baghdad's ability to revive the ISI. He took over the leadership of the organization when it was at its weakest point. However, he went on to transform it into "... a classic-styled terrorist group built on an underground organisation" (Holmquist, 2015, p. 16). This is because by 2014 the group had amassed over 30 000 fighters for the Sunni army. Besides numbers, Al-Baghdad recruited experienced former Hussein military officers, especially those from the Republican Guards and these converted ISIS into a professional fighting force (Gerges, 2014, p. 339). Additionally, Patel (2015) observes that the military successes of ISIS have been propelled by the non-dilution of its ideological commitments strengthened by the full incorporation of former Baathists into its organizational structure. This has led some observers to plausibly refer ISIS as "... a hybrid of terrorists and an army" (Patel, 2015, p. 3). This confirms Hove and Chenzi's (2017, p. 68) observation that indoctrination is the backbone of terrorism, especially suicide terrorism.

In April 2013, Al-Baghdad renamed the group the Islamic State of Iraq and Levant (ISIL) (Gulmohamad 2014) prompting its intervention and expansion into the Syrian civil war. This was the case because the Syrian government of Bashar al-Assad had been weakened by the attacks of the US and its Western allies who backed the "Free Syrian Army" 
(Hove \& Mutanda, 2015). According to Warrick (2015), the Arab Spring was a wonderful opportunity for the re-emergence of ISIS (or ISI as it was known). This is because they thought that Muslims around the world were to rally and overthrow corrupt regimes thereby enabling them to rise to power but this did not happen. Instead of calling for Islamic governments the peaceful demonstrations in Arab countries called for democracy and economic liberty among other reforms and demands (Hove \& Ndawana, 2017).

The mishandling of the peaceful demonstrations by Assad in Syria influenced the jihadists to seize the opportunity in the same way they did in Iraq during the US invasion of Iraq (Warrick, 2015). Moreover, Cockburn (2014) notes that ISIS's swift rise since Abu Bakr al-Baghdadi took its reigns was due to the uprising of the Sunni in Syria in 2011. This prompted the Iraqi Sunni to also protest about their political and economic marginalisation from the time when Saddam Hussein was ousted and killed. The peaceful demonstrations since the end of 2012 witnessed few concessions from Iraq's Shiadominated government. The government was convinced that the protesters did not need reform but a revolution aimed at returning their community to power. This led to the alienation of between five to six million Iraqi Sunnis and these were responsive towards armed action by ISIS (Cockburn, 2014). Additionally, Assad exacerbated the situation, "... by sending Alawi death squads into Sunni villages to murder and rape, or by releasing violent Salafists from prison in 2011 at the same time he was targeting secular, peaceful activists for detention and assassination" (Yassif-Kassab, 2015). More so, blame goes to the Iranian-backed Shia jihadist militias of Lebanese and Iraqi origin who fought on the side of Assad (Yassif-Kassab, 2015).

Furthermore, in an audio message in early April 2014 Baghdadi included a terrorist organization and al-Qaeda affiliate operating in Syria by the name Jabhat al-Nusra (JN) as part of ISIS (Gulmohamad, 2014, p. 2). However, the leader of JN, Abu Muhammad al-Julani denied the merging of his group with ISIS. Instead, he made known his allegiance to Osama bin Laden's successor and leader of al-Qaeda, Ayman al-Zawahiri (Gulmohamad, 2014, p. 2). Nevertheless, another version argues that Al-Baghdad sent Abu Mohammad al-Golani, a Syrian to create JN in Syria in a drive to realize the Syrian part of the long desired Islamic State (Cockburn, 2014; Holmquist, 2015). The confusion was further aggravated by the fact that Zawahiri was also involved in the plans to establish JN (Zelin, 2014, p. 5). However, Tucker (2014) contends that JN “... is an organically grown extremist organization within Syria that derived from old cadres of AQI, but has since re-emerged in Syria's 2011 uprisings to become al-Qaeda's preferred affiliate within the region" (p. 2). This is because as in Iraq, Sunni resentment in Syria unfolded in the context of the domination of the Bashar al-Assad regime by the Alawite sect (Gerges, 2014).

Increasing ISIS's influence outside Iraq's borders in rebelliousness of the al-Qaeda's Central Leadership (AQC) appears to be the agenda of Al-Baghdad (Gulmohamad, 
2014). As a result, following months of disagreements and rows between ISIS and AQC Al-Zawahiri proclaimed the dissociation of AQC from ISIS (Gulmohamad, 2014). To this end, Weiss and Hassan (2015) assert that ISIS is actually the latest front in a bloody culmination of a long-running dispute within the ranks of international jihadism. Problems are centred on how to wage the holy war and who to target from Shia, Alawites, and other minority sects and ethnicities, Americans to their "Zionist-crusader" allies. This illustrates the emergence of radical and extremist autonomous groups from and within the al-Qaeda.

Furthermore, the relationship between ISIS and al-Qaeda from the onset of ISI since 2006 remains hazy as Al-Baghdad has maintained that his group "is not and has never been an offshoot of Al-Qaeda" (Blanchard et al., 2015, p. 2). It is an independent entity as the ISIS leadership before him gave the al-Qaeda leadership deference as opposed to allegiance Zelin (2014) shares the same sentiments where he argues that al-Qaeda and ISIS had distinct backgrounds, leadership styles and aims. However, these have been confused to be one because of the marriage of convenience the two groups entered into in 2004. Among other things, Zarqawi had a criminal past and extreme view of takfir (heresy accusation of another Muslim justifying his killing) that led to distrust and friction between him and Osama bin Laden when they first met in 1999 in Afghanistan (Zelin, 2014). According to Crooke (2014), ISIS's extreme and radical interpretation of Islam has also brought divisions in Saud Arabia where it is believed to share a lot and appealed to many (both youths and the elite) who subscribe to strict Salafist ideology (Wahabbism). They embrace ISIS as constituting "Sunni fire" fighting "Iranian Shiite fire" but what they do not see is that ISIS is also a threat to them too. In addition, ISIS and JN (now pro-al-Qaeda) are believed to differ in their methodology with the latter favouring a gradualist approach and willing to work with other groups and establish an Islamic state at last, whereas the former is inclined to a more direct approach where territory seized is immediately declared an Islamic state and sharia imposed (Friedland, 2015). This took place in Raqqa in Syria between late 2013 and early 2014 where ISIS seized control of the area after defeating all the factions there and from then on served as its power base (Friedland, 2015).

Moreover, ISIS also managed to capture huge territory in Iraq taking Anbar province's Fallujah and Ramadi areas and Mosul, the country's second largest city in the north in 2014 (Friedland, 2015). In fact, it was at the mosque in Mosul that Baghdadi first appeared and declared himself Caliph and called for the intensification of jihad to serve Allah.

Overall, one can primarily and plausibly shoulder the emergence of ISIS and its consequent horrendous operations on the United States. Warrick (2015) points out that ISIS was a creation of the US invasion of Iraq in 2003. Similarly, Ogur (2014) notes that ISIS's predecessors emerged as a result of the US invasion of Iraq. Moreover, the US in 
2004 released the current leader of ISIS, Al-Baghdad from Camp Bucca and in 2013 most ISIS militants escaped from the US-controlled Abu Graihb Prison. Furthermore, it was the CIA who trained Syrian opposition fighters in Jordan that have now joined the ranks of ISIS in greater numbers following their defection from the erroneously considered moderate Syrian rebel groups such as the Free Syrian Army (FSA). Again, a number of weapons from the United States ended up in the hands of ISIS (Ogur, 2014). As observed by Ayad Jamal Al-Din (2014), weakening the Syrian regime by arming and aiding the FSA by the US has been futile because it all benefits ISIS both in Syria and Iraq as it is actually the one causing problems in the two countries.

In line with the re-emergence of ISIS soon after the total pull-out of US forces by Barak Obama in 2011, ISIS's rise is also attributed to Obama as opposed to Bush. This is because Bush managed to keep radical Islamist groups under control in Iraq (Merry, 2014). Since the beginning of US forces' pull-out in 2009 ISIS regrouped and rethought its strategies and by late 2009 terror attacks targeted at overthrowing the Iraqi government had already begun. Added to this, was Obama's failure to decisively intervene in Syria to prevent it from being turned into an ISIS haven (Merry, 2014). However, it is important to note that Bush has his fair (if not the biggest) share of blame to the rise of radical Islamists and fundamentalists including ISIS. This is in light of the way he handled the 9/11 attacks which he did in a way that inflamed anti-American fervour and stirred sectarian violence in many countries when he invaded Iraq in 2003. Indeed, in light of the emergence of ISIS and the destruction it has caused, "... the Bush decision to invade Iraq ... ranks among the greatest foreign-policy fiascos in the nation's history" (Merry, 2014).

Essentially, it was Bush who made the provocative statement following the $9 / 11$ attacks that:

I also want to speak tonight directly to Muslims throughout the world ... Our enemy is a radical network of terrorists, and every government that supports them.... Our war on terror begins with al Qaeda, but it does not end there. It will not end until every terrorist group of global reach has been found, stopped and defeated ...We will starve terrorists of funding, turn them one against another, drive them from place to place, until there is no refuge or no rest. And we will pursue nations that provide aid or safe haven to terrorism. Every nation, in every region, now has a decision to make. Either you are with us, or you are with the terrorists (Bush, 2001).

Furthermore, Creamer (2014) underscores the laying of conditions for the rise of ISIS by Bush when he noted that Bush's "de-Bathification program" eliminated all vestiges of Sunni power in Iraqi society and set the stage for the Sunni insurrection against American occupation and the new Shiite-led government. Bush disbanded the entire Sunni-dominated Iraqi Army and bureaucracy. He didn't change it. He didn't make it 
more inclusive of Shiites and Kurds. He just disbanded it. It is no accident that two of the top commanders of today's ISIL are former commanders in the Saddam-era Iraqi military.

It is imperative to realise that Iraq was invaded in 2003 for economic (oil), security (weapons of mass destruction and that Saddam Hussein supported terrorists) and political reasons (to depose Saddam Hussein a dictator) (Bassil, 2012; Lieberfeld, 2005). Similarly, Pillar (2008) asserts that, "Iraq's oil resources are part of what makes it an important and influential state in the Middle East, and thus one where it was hoped that change would serve as a catalyst for change elsewhere in the region". The Bush administration anticipated that deposing Saddam Hussein would lead to the removal of all regimes in the entire Middle East antagonistic to the US and its wellbeing in the region, or compel them into cooperation, or to be overthrown by their citizens in an effort to emulate the liberation of the Iraq people by the US (Gause III, 2009). After the removal of Saddam Hussein the regime change agenda of the US failed and Iraq declined into a failed state (Hove, 2017).

Besides, the US, Turkey also played a significant role, particularly in opening (by not enforcing restrictive measures on migrant movement) its 550 mile-land border with Syria to free passage of would-be ISIS fighters (Dorsey, 2014). Turkey, Qatar and Saudi Arabia among other countries have been accused of providing controversial ISIS affiliates in Syria with arms among other forms of assistance under the pretext that they would fight Assad (Dorsey, 2014). Ironically, Assad himself (including his allies Iran and Russia) also contributed to the rise of ISIS because he supported it when it was still AQI targeting US troops in Iraq. Moreover, he facilitated the flow of foreign fighters and logistics into Iraq, particularly from Saudi and North Africa who today have become the largest of ISIS's fighting contingents. The same support structures and logistical links and networks originally established with Syrian assistance are now utilised against it. Most of the ISIS fighters were arrested and jailed in Syria on terrorism charges but were controversially released in a series of amnesties (Dorsey, 2014).

Contrary to the view that shoulder the rise of Daesh on Syria and Iran, the leader of Hezbollah has maintained that it is sheer nonsense to believe that the countries that are fighting hard to defeat ISIS created it. ISIS was a creation of the United States' CIA and its Middle East allies' intelligence through establishing al-Qaeda to fight the Soviets in Afghanistan (Middle East Observer, 2015). However, in 2014 fear had already been provoked in many of these countries as it increasingly became clear that they were soon to become targets of battle-hardened Sunni fighters, especially following the creation of a Caliphate by ISIS in northern Iraq and Syria (Cockburn, 2014). This is because the outfit has made its agenda very clear that it wants to return to the pre-First World War status of the Muslim world in the Middle East and other parts of the globe. In the following section I focus on ISIS ideology and agenda. 


\section{ISIS ideology and agenda: the roots}

ISIS has been viewed by others as not an ordinary jihad group influenced and controlled by al-Qaeda. Its disobeying of the $\mathrm{AQC}$ and al-Zawahiri many times reinforces the fact that ISIS has its own conception and standpoint (Gulmohamad, 2014). Simms (2014) notes that ISIS whilst frequently thought as an 'al-Qaeda' group, the accurate understanding of the group can only be made by pointing out that its previous leaders maintained a significant degree of autonomy despite their swearing of loyalty to al-Qaeda. In addition, Friedland (2015) argues that AQI while still subordinate to AQC managed to establish its own network of supporters and fighters during the course of the Iraq insurgency allowing it in practice to be autonomous and be able to develop an ultraviolent brand of jihad of its own making. Resultantly, it pledges loyalty to AlBaghdadi, its leader and not Al-Zawahiri. In this regard, Friedland (2015) believes that this was caused by generational differences between Osama Bin Laden aligned jihadists who fought in Afghanistan and Al-Zarqawi's compatriots whom he fought alongside in Iraq including the current leader Al-Baghdad. This is reflected in ISIS's song of faith (nasheed) translated as:

We have closed ranks and pledge bay'ah to Baghdadi,

For our emir in our Iraq and ash-Sham (Gulmohamad, 2014, p. 2).

To this end, ISIS is believed to be a Salafist-jihadi organization where Salafism is perceived as an extremist politico-religious movement within Islam that seeks to restore the golden era of the dawn of Islam (ITIC, 2014, p. 2).

Others have argued that ISIS is more of an idea and approach as opposed to an organization. Besides being the most radical of the extremist organizations, ISIS's faith is based on seeking punishment for regimes and rulers opposed to and resisting its ideology (Gulmohamad, 2014). The most extreme interpretation of Islamic religious law (sharia) is the basis of governing the supranational Islamic Caliphate envisaged to come into being in Islam's golden era modeled after the first Caliphs that emerged following Muhammad's death (ITIC, 2014). In this regard, the Salafist ideology holds that a jihad has to be waged against both internal and external foes and it is the personal duty of every Muslim. In fact, in his first appearance statement, Al Baghdadi proclaimed that Ramadan is a month to wage Jihad, a month when the Prophet made armies to fight enemies of God, the month where he would wage Jihad on polytheists! He also urged people to take advantage of this month and obey Allah. Allah has blessed and created us to single him out in monotheism, and to establish his religion. Allah said, "I have not created the human and the jinn except to worship". Allah has ordered us to fight his enemies and wage jihad for him to establish his religion. Allah said, "I have ordered you to fight (for Islam) even though you do not like it", He said, "and fight them so there is no discord and this is for all people to adopt in their life for Allah". 
This is even the case with al-Qaeda and other global jihad organizations that sprang up motivated by Salafist jihadism (ITIC, 2014). However, some differences exist and these are caused by the fact that Salafi philosophy espoused by ISIS does not accommodate theological diversity (Holmquist, 2015). While other jihad organizations like al-Qaeda view the West, especially the United States and Israel as their primary target and enemy of the Muslims, ISIS views the West as a secondary target and its real and acute enemies are actually the infidel and apostate regimes in the Muslim world (Gerges, 2014). This made the deepening of the rift between JN and ISIS due to the fact that the latter's entire council leadership (8-13 members) consisted of Iraqi nationals and all are former military officers in Saddam's regime (Gulmohamad, 2014). Consequently, the official separation between ISIS and al-Qaeda marked the beginning of fierce hostilities between the groups that have seen many battles and infighting in Syria and Iraq between ISIS and JN (Gulmohamad, 2014). This prolonged the survival of Assad in Syria (Holmquist, 2015, p. 18). Again, instead of focusing on defeating Assad ISIS focused on establishing its Islamic State (Friedland, 2015).

While ISIS has its roots in Iraq, it has affiliations in Syria, Lebanon, Libya, Egypt, Nigeria, Saudi Arabia, Yemen and Afghanistan (Blanchard et al., 2015). ISIS in Lebanon was established in 2014 led by Abu Sayyaf al-Ansary who proclaimed allegiance to the ISIS leadership. Tripoli in northern Lebanon is believed to be the fertile ground for its extreme ideology where the group arose (Gulmohamad, 2014). The Shura Council of Islamic Youth based in the eastern city of Derna in Libya officially declared their allegiance to Al-Baghdad and ISIS in June 2014 (The Maghrebi Note, 2015). In February 2015 ISIS executed 21 Egyptian Christian citizens (Hove, 2017). In addition, groups in Yemen, Egypt and Algeria have already proclaimed their allegiance to Al-Baghdad both in good and bad times (The Maghrebi Note 2015). Boko Haram in Nigeria did the same in March 2015 (Friedland, 2015). Consequently, the contagious effect of terrorist groups and their ability to take advantage of the vulnerabilities of the Islamic region in the midst of the worst civil wars in modern history is illustrated by the operations of ISIS. This is in line with the agenda (short, medium and long-term goals) of ISIS's establishment of a Caliphate out of the debris of nation states established in the Middle East following the First World War.

The 2014 and 2015 disintegration of Iraq and Syria due to ISIS's operations has been viewed as part of the upheaval favourably conditioning the creation of the envisioned Islamic Caliphate in the Middle East (ITIC, 2014). The planned Islamic Caliphate intends to encompass the whole of Iraq, Syria, Jordan, Lebanon, Israel, the Palestinian Authority, other countries in the Middle East, North Africa, Asia, the Caucasus and Spain and the Balkans among other parts of Europe that were once under Muslim rule (ITIC, 2014). In fact, Al-Baghdad self-proclaimed himself as Caliph Ibrahim II taking it from Caliph Ibrahim I who ruled the Ottoman Empire between 1640-1648 and whom he seem to 
be of the same lineage with (Tucker, 2014). Apparently, this reveals how serious and enormous the threat ISIS poses to the region and international peace and security.

Obviously, ISIS's grand goal is nothing short of world domination of Islam (Eckman, 2014). This is even supported by its famous official slogan: baqiya wa tatamaddad ('remaining and expanding') (Al-Tamini, 2015). Additionally, Baghdadi glorified the ISIS fighters after ISIS's invasion of Ramadi in May 2015 vowing that Allah wished and the prince of the believers reported yesterday, and before yesterday the conquest of al-Anbar city is the start of the conquest of Baghdad, Najaf and Karbala, and destroying the idols and shrines on the heads of its owners by the help of Allah the Almighty. This conquest marks the start of bigger conquests. I congratulate the caliph of the Muslims, the believers' prince, Abu Bakr-al Baghdad al-Hussany al-Quraishy and congratulate Muslims living in the Caliphate and the Islamic State on freeing the land of Ramadi with Allah's permission, the most high, we are going to Baghdadi, the repulsive Najf and filthy Karbala.

However, the caliphate idea of Baghdadi has been rejected by other Islamic leaders saying it lacks broad support across Islam. Those inclined to al-Qaeda have insisted that a caliphate needs broad consensus on behalf of all Muslims and scholars as opposed to a mere proclamation by an individual following military victory. Additionally, and sharing the same sentiments with al-Qaeda on the basis of Islamic jurisprudence, Baghdadi's caliphate claims have been refuted by about 126 distinguished scholars and clerics who contended that a caliph without a general consensus is a fitna (strife or sedition in Arabic) (Eckman, 2014; Wood, 2014).

The Islamic State constitutes a hybrid threat and this is attested by its transnational aspirations, a combination of tactics, structured formations, and the use of terror and criminal activities (Jasper \& Moreland, 2014). To this end, to those opposed to ISIS the decisive intervention of the world's superpowers such as Russia in Syria fighting ISIS although viewed with mixed feelings is necessary in order to curb its menace before it further slips out of control (Dyer, 2015). This is because earlier efforts by the United States to degrade and ultimately defeat ISIS both in Iraq and Syria had proved to be long and unsuccessful. Among other things this was due to divided attention and efforts with some directed at ousting the Syrian leader, Assad instead of simply focusing on defeating ISIS (Blanchard et al., 2015). Resultantly, both ISIS and Assad have hitherto survived the US's ill-informed and divided strategies to simultaneously deal with both. While the 2015 ISIS gains were later on reversed, it had demonstrated its capacity to destabilise many countries globally (Byman, 2017). This makes its potential to continue posing threats to international peace and security not far from over. 


\section{Conclusion}

This article traced the origins of ISIS and asserts that it has its roots in the Jordanian Zarqawi's TJWJ. It has been known by various names that include Al-Qaeda in the Land of the Two Rivers, or simply as al-Qaeda in Iraq or AQI, Majlis Shura al-Mujahedin, and the Islamic State of Iraq before it rebranded itself to the Islamic State of Iraq and alSham and lastly the Islamic State since 2014. Although it is debateable the United States invasion of Iraq in 2003 laid the groundwork for the emergence of Islamic radicalism in Iraq and the Middle East. The intervention inflamed anti-American fervour and stirred sectarian violence in many countries. This is because ISIS's predecessors emerged and got legitimacy as a result of the US invasion of Iraq. Although the US managed to aid the al-Maliki government to weaken AQI between 2006 and 2007 the decision by Obama to fully withdraw the US military from Iraq in 2011 assisted the re-emergence of ISIS in full force. Additionally, the CIA's ill-conceived training of Syrian opposition fighters in Jordan helped the growth of ISIS's ranks and weaponry base as these have joined it in greater numbers. Consequently, the US and its allies in the region that include Turkey, Qatar and Saudi Arabia among others also played a significant role in propping up ISIS by providing controversial ISIS affiliates in Syria with arms among other assistance under the pretext that they would fight Assad.

Assad himself and Iran also shoulder a share of blame as ISIS's predecessors, especially AQI received aid and assistance from the two countries when it was still fighting the US in Iraq. Consequently, ISIS managed to realise some of its goals by establishing its Islamic state in parts of Iraq and Syria. It also spread its tentacles to Lebanon, Libya, Nigeria, Egypt, Saudi Arabia, Yemen and Afghanistan thus it was on its course towards world domination. However, its ambitions were thwarted by the decisive intervention of Russia which began in late September 2015 with the objective of stopping the ISIS menace. More so, ISIS's 2015 attack on France and Belgium, downing of Russia's airliner over Egypt (Hove \& Chenzi, 2017, p. 72) and the beheading of a Chinese national intensified offensives against the terrorist organisation in a drive to bring it to an end. Allow me to urge the US and its allies to rally behind the Bashar al-Assad regime in Syria in a drive to hasten the down fall of ISIS. It is tactical and strategic for the US and its allies to render their military assistance to Assad than to the FSA, Turkey, Jordan, Saudi Arabia and Quarter some of whose efforts, weaponry and forces find their way to ISIS.

\section{References}

1. Al-Din, A. J. (2014, June 12). Iraqi Politician: Obama Is Supporting ISIS in Syria - Will He Support ISIS in Iraq Too? MEMRI TV. Retrieved from www.barenakedislam.com/ 2014/06/12/obama-is-supporting-the-isis-terrorists-in-syria-will-he-support-themin-iraq-too-now/.

2. Al-Tamini, A. J. (2015, February 3). Book Review: ISIS: Inside the army of terror. Syria Comment. Retrieved from www.joshualandis.com/blog/book-review-isis-inside-armyterror/. 
3. Altschular, G. C. (2015, September 24). Book review: Black Flags: the rise of ISIS by Joby Warrick. SFGate. Retrieved from www.sfgate.com/books/article/Black-Flags-TheRise-of-ISIS-by-Joby-6527628.php.

4. Bassil, Y. (2012). The 2003 Iraq War: Operations, Causes, and Consequences. Journal of Humanities and Social Science, 4(5), 29-31.

5. Blanchard, C. M., Humud, C. E., Katzman, K., \& Weed, M. C. (2015). The "Islamic State" Crisis and U.S. Policy. Washington, DC: Congressional Research Service.

6. Blumenau, B. (2014). ISIS: understanding the threat and its implications for the West. Current Affairs in Perspective, 6, 1-7.

7. Bunzel, C. (2015). From Paper State to Caliphate: The Ideology of the Islamic State. The Brookings Project on U.S. Relations with the Islamic World Analysis Paper, No. 19. Washington: Center for Middle East Policy.

8. Bush, G. W. (2001). Address to a Joint Session of Congress and the American People. The White House. Retrieved from http://georgewbush-whitehouse.archives.gov/news/re leases/2001/09/20010920-8.html.

9. Byman, D. (2017, June 8). Beyond Iraq and Syria: ISIS' ability to conduct attacks abroad. Testimony before the Senate Committee on Foreign Relations. Brookings. Retrieved from https://www.brookings.edu/testimonies/beyond-iraq-and-syria-isis-ability-toconduct-attacks-abroad/

10. Cockburn, P. (2014, June 16). Who are ISIS? The rise of the Islamic State in Iraq and the Levant. The Independent (UK). Retrieved from www.independent.co.uk/news/ world/middle-east/who-are-isis-the-rise-of-the-islamic-state-in-iraq-and-the-le vant-9541421.html.

11. Creamer, R. (2014, September 15). Bush/Cheney created conditions that led directly to ISIL. The Huffington Post. Retrieved from www.huffingtonpost.com/robert-creamer/ bushcheney-created-condit_b_5820916.html.

12. Crooke, A. (2014, August 27). You Can't Understand ISIS if you don't know the History of Wahhabism in Saudi Arabia. The Huffington Post. Retrieved from www.huffington post.com/alastair-crooke/isis-wahhabism-saudi-arabia_b_5717157.html.

13. Dorsey, J. M. (2014). The rise of the Islamic State: who is to blame? Mideastsoccer. Retrieved from www.twitter.com/mideastsoccer.

14. Dyer, G. (2015, October 9). Putin's attacks on ISIS trump US talk. Zimbabwe Independent. Retrieved from www.theindependent.co.zw/2015/10/09/putins-attacks-on-isistrump-us-talk/.

15. Eckman, J. (2014, October 25). Understanding ISIS: Its origins, its ideology and its context. Issues in Perspective. Grace University. Retrieved from https://graceuniversity. edu/iip/2014/10/understanding-isis-its-origins-its-ideology-and-its-context/.

16. Friedland, E. (2015). The Islamic State. The Clarion Project Special Report. The Clarion Project. Retrieved from https://clarionproject.org/the-islamic-state-isis-isil/.

17. Gause III, F. G. (2009). The Return of the Old Middle East: How to Win at Balance-of-Power Politics. Foreign Affairs. Retrieved from www.foreignaffairs.com/articles/64844/ f-gregory-gause-iii/the-return-of-the-old-middle-east. 
18. Gerges, F. A. (2014). ISIS and the Third Wave of Jihadism. Current History, 113(767), 339-343.

19. Ghosh, B. (2014, August 14). ISIS: A Short History: The terrorist group's evolution from fervid fantasy to death cult. The Atlantic. Advance Readings for October 16, 2014 Foreign Affairs Discussion at the Burlington Public Library on "The Islamic State”, Burlington, USA.

20. Gulmohamad, Z. K. (2014). The rise and fall of the Islamic State of Iraq and Al-Sham (Levant) ISIS. Global Security Studies, 5(2), 1-11.

21. Hadra, D. (2015). ISIS: Past, Present and Future?: Pro-ISIS Media and State Formation. Boston: The College of Arts and Sciences, Boston College.

22. Holmquist, E. (2015). ISIS and Hezbollah: conduits of instability. Stockholm: FOI Swedish Defence Research Agency.

23. Hove, M., \& Chenzi, V. (2017). Terrorism: A Reflection of the Dynamics of Contemporary Suicide Terrorism. Conflict Studies Quarterly, 20, 67-89.

24. Hove, M., \& Mutanda, D. (2015). The Syrian Conflict 2011 to the Present: Challenges and Prospects. Journal of Asian and African Studies, 50(5), 559-570.

25. Hove, M., \& Ndawana, E. (2017). Regime Change Agenda: The Egyptian Experience from 2011 to 2015. Contemporary Arab Affairs, 10(1), 32-50.

26. Hove, M. (2017). Post-Gaddafi Libya and the African Union: Challenges and the Road to Sustainable Peace. Journal of Asian and African Studies, 52(3), 271-286.

27. The Meir Amit Intelligence and Terrorism Information Center (ITIC) (2014). ISIS: Portrait of a Jihadi Terrorist Organization. ITIC. Retrieved from www.terrorism-info.org.il/ en/article/20733.

28. Jasper, S., \& Moreland, S. (2014). The Islamic State is a Hybrid threat: why does that matter. Small Wars Journal. Retrieved from http://smallwarsjournal.com/jrnl/art/theislamic-state-is-a-hybrid-threat-why-does-that-matter.

29. Lieberfeld, D. (2005). Theories of Conflict and the Iraq War. International Journal of Peace Studies, 10(2), 6-15.

30. Lister, C. (2014, December 1). Profiling the Islamic State. Brookings Doha Center Analysis Paper, No. 13. Brookings. Retrieved from www.brookings.edu/research/re ports2/2014/12/profiling-islamic-state-lister.

31. Mehta, V. (2016. April 12). Update on Iraq crisis in Iraq, only non-military solutions can end the conflict. London: All Party Parliamentary Group on Third World Solidarity.

32. Merry, R. W. (2014, September 17). Who is more responsible for the rise of ISIS? Obama or Bush? The National Interests. Retrieved from http://nationalinterest.org/feature/ who-more-responsible-the-rise-isis-bush-or-obama-11296.

33. Middle East Observer. (2015, June 7). Hezbollah leader on who created Daesh (ISIS)English Subtitles. Retrieved from www.youtube.com/watch?v=-mQ7e-xuV3I.

34. Ogur, Y. (2014, July 1). Barack Obama: the chief sponsor of ISIS. Daily Sabah. Retrieved from www.dailysabah.com/opinion/2014/07/01/barack-obama-the-chief-sponsorof-isis. 
35. Page, R. (2015). ISIS and the sectarian conflict in the Middle East. Research Paper 15/16. London: House of Commons Library.

36. Patel, D. S. (2015). ISIS in Iraq: what we get wrong and why 2015 is not 2007 redux. Middle East Brief. Massachusetts: Crown Center for Middle East Studies.

37. Pillar, P. (2008). Iraq Critics Reject Claim War was for Oil. The Stanford Review. Retrieved from http://stanfordreview.org/article/iraq-critics-reject-claim-war-was-oil/.

38. Simms, M. (2014). ISIS: background, ideology and capabilities. Human Security Centre, Security and Defence, 2(6).

39. The Maghrebi Note. (2015). ISIS in Libya: the origins of ISIS in Libya and its methodology. The Maghrebi Note. Retrieved from https://themaghrebinote.files.wordpress. com/2015/03/isis-and-its-origins-in-libya-themaghrebinote.pdf.

40. Tucker, C. (2014, July 13). The Islamic State: origins, goals and future implications. The Eurasia Brief. Washington: The Eurasia Center.

41. Warrick, J. (2015). Black flags: the rise of ISIS. New York: Doubleday.

42. Weiss, M., \& Hassan, H. (2015). ISIS: Inside the Army of Terror. New York: Regan Arts.

43. Wood, G. (2014, September 2). What ISIS's leader really wants: the longer he lives, the more powerful he becomes. The New Republic. Retrieved from www.newrepublic.com/ article/119259/isis-history-islamic-states-new-caliphate-syria-and-iraq.

44. Yassif-Kassab, R. (2015, March 28). Isis: Inside the Army of Terror; The Rise of Islamic State - review. The Guardian. Retrieved from www.theguardian.com/books/2015/ mar/28/inside-army-of-terror-rise-of-isalmic-state-review.

45. Zelin, A. Y. (2014). The War between ISIS and al-Qaeda for supremacy of the Global Jihadist Movement. The Washington Institute for Near East Policy, 20, 1-11. 